\title{
I DO IT BETTER: HOW SOCIAL AND EMOTIONAL LEARNING ENVIRONMENT ENHANCES ASSESSMENT for Learning Strategies in Science Classrooms
}

\author{
Renuka V. Sathasivam \\ Suzieleez Syrene Abdul Rahim ${ }^{\text {a }}$ \\ University of Malaya
}

\begin{abstract}
This paper describes part of a more extensive national study on Malaysian teachers' classroom assessment practices. The main study used a priori coding framework containing four-level performance ratings (i.e., Distinguish, Proficient, Basic, and Unsatisfactory). The findings revealed that a large majority of teachers' practices were at an unsatisfactory level. Among the 30 science teachers, only two teachers were categorised at the Basic level; the rest were at the unsatisfactory level. The present study used a qualitative approach to compare two teachers at basic and unsatisfactory levels and investigated if teachers' social and emotional competencies (SEC) affect the implementation of three Assessment for Learning (AfL) strategies. Three video recordings for each teacher were the main source of data. The findings revealed that the teacher with SEC increased student engagement. The research findings have implications on educational assessment policy and, particularly, teacher education programmes to incorporate elements of SEC to improve teachers' $A f L$ skills.
\end{abstract}

Keywords: Assessment for Learning; Social and emotional competencies: Science teachers; Classroom Discourse

\section{Introduction}

Assessment for Learning ( $\mathrm{AfL}$ ) has consistently shown positive educational outcomes for all grade levels, for a broad spectrum of subjects and various educational settings (Andrade \& Cizek, 2010; Black \& Wiliam, 1998; Hattie \& Timperley, 2007; Westbrock et al., 2020). AfL has been conceptualised as a series of strategies to enhance students' robust understanding of content matter (Black \& Wiliam, 2009, Wiliam, 2011). These strategies are central but not mandatory, and teachers are given a higher degree of flexibility on how they implement the AfL approach (Leahy \& Wiliam, 2012). Since the implementation of AfL is left open to teachers' initiatives and processes of adaptation, literature has shown that teachers are not successfully integrating AfL strategies in their daily lessons (DeLuca et al., 2012; Heritage et al., 2009; Klenowski, 2011; Marshall \& Drummond, 2006).

There are two reasons why teachers might be reluctant to implement these strategies, or even when they do; the enterprise is unsuccessful. Firstly, Willis (2011) had suggested that the desired outcome for AfL (i.e., learner autonomy) had remained elusive as the implementation of AfL has not been viewed as an enterprise of participation. More commonly identified as teacher-student relationships, participation should include 'observation, conversations and telling personal stories' (Willis, 2011, p. 412). Through these teacher-student relationships, opportunities are provided for students to make meaning and develop expertise (Aspelin, 2012). However, many teachers rarely engage students in authentic conversation and formulate rich classroom discourses (Lloyd, Kolodziej \& Brashears, 2016).

Correspondence can be directed to: suzieleez@um.edu.my 
Secondly, even if teachers do attempt to engage students in these classroom discourses, the process of getting teachers and students to share and develop expertise requires time and a mindset change. Many teachers face tensions between standardised testing and the AfL process; thus, finding the time for these learning activities diminishing (Hopfenbeck et al., 2015). Teachers' emotions are those of anxiety and despair as, on the one hand, they are held accountable for their students' success and on the other hand, they are not able to give their total commitment to the AfL process (Dori, 2003; Hayward \& Spencer, 2010). Thus, Steinberg (2008, p. 42) was not wrong to claim that assessment and, particularly AfL process, would invoke "strong emotions of anxiety, irritation and even despair".

However, the social and emotional context of the AfL is seldom mentioned or explored (Hargreaves, 1998). AfL process is complex, but this complexity multiplies when one must consider the social and emotional context, leading to scholars shying away from this kind of research (Steinberg, 2008; Wiliam, 2018). Therefore, a study on AfL must consider the social or emotional aspect; if not, it produces a partial or likely misleading account of what is going on and how it may improve. Since AfL hinges heavily on student-teacher participation and relationships, there may be a possibility that enhancing teachers' social and emotional competencies (SEC) (Ryerse \& Ark, 2018; Weissberg et al., 2015) could influence the quality of teachers' implementation of AfL strategies (Collie, 2017).

\section{Literature Review}

Traditionally, research on AfL has been solely investigated as a cognitive process (Black \& Wiliam, 1998). As such, researchers developed strategies to help teachers to implement $A f L$ in the classrooms. Wiliam and Thompson (2007) had provided five "key strategies" to implement AfL - (i) sharing learning goals, (ii) engineering good classroom discussions, (iii) providing constructive feedback, (iv) promoting peer assessment and (v) self-assessment. AfL principles are based on student autonomy and lifelong learning because students are involved in the entire process. Even though directives from policy documents encourage teachers to implement these strategies that lead to student autonomy and participation, teachers cannot successfully do so (Janssen et al., 2015; MOE, 2013).

Moreover, teachers operating in high power-distant cultures (Hofstede, Hofstede \& Minkov, 2010) are often seen as knowledge keepers. Changing this role can be challenging (Marshall \& Drummond, 2006; Willis, 2010). Often, these teachers' classrooms are teacher-centred, and they prefer to maintain discipline and control over class activities, especially where great importance is given to formal assessment (Eccles \& Roeser, 2011). Teachers are not in favour of students challenging them, and to avoid these situations, the teachers use non-Socratic discourses. When teachers do this, they relinquish student autonomy in their learning process, which is the heart of AfL (Swaffield, 2011).

The reasons for the lack of success in AfL could be the deficiency in studies of how teachers establish and sustain the social and emotional aspects of AfL. Re-contextualizing AfL from a sociocultural theory places the spotlight on the role of identity (Shepard, 2019). Acknowledging who a person is and envisioning who that person might become is essential to meaningful participation. To have meaningful class participation, all life experiences become relevant to learning, including the child's exosystem and macrosystem cultural practices. The socialisation of students must be met with the student's sense of safety and respect for meaningful learning opportunities (Heritage, 2013).

Emotion and cognition are now understood to be inextricably linked (Rogers, 1969, 1983). Rogers (1969, p. 106) held that "certain attitudinal qualities which exist in the personal relationship between the facilitator and the learner" yield significant learning. Facilitation requires at least the facilitator's initial genuine trust in learners, followed by creating an acceptant and empathic climate. Thus, Poplin and Weeres (1994, p. 12) investigated the question, "What is the problem with schooling?" Their answer was relationships, particularly between teachers and students. They found that students who have positive experiences often involve "individuals who care, listen, understand, 
respect others and are honest, open, and sensitive". Positive student outcomes are often associated with positive relationships, empathy, warmth, and encouraging thinking and learning and are seemed to be more effective than other educational innovations (Cornelius-White, 2007)

Creating social and emotional learning environment when implementing AfL is no easy task. Teachers do not only focus on the cognitive enhancement of their students, but they now need to incorporate social competencies such as being empathic, being able to cooperate and work in teams as well as developing trust among peers into the assessment process (Black \& Wiliam, 2003; Schneider \& Randel, 2010; Taylor \& Parsons, 2011; Willis, 2010). However, the success of AfL implementation lies in teachers' teaching ability and their relational skills (Chen, 2008; Humphrey, 2013; Osher et al., 2020; Pianta et al., 2008). It is because students who had experienced some form of support from their teachers showed increased academic achievement and motivation to learn (Fraire et al., 2013; Hen \& Goroshit, 2016).

Teachers can enhance social and emotional competencies to improve their AfL implementation. These competencies help teachers develop solid and supportive relationships with their students (Jennings \& Greenberg, 2009). Jennings et al. (2013) argued that social-emotional competencies provide the necessary skill base and dispositions that help teachers to form supportive relationships with their students and effectively manage their classrooms. Collaborative for Academic, Social, and Emotional Learning (CASEL) (2019) had provided five competencies which are (i) manage emotions (self-awareness), (ii) set and achieve positive goals (self-management), (iii) feel and show empathy for others (social awareness), (iv) establish and maintain positive relationships (relationship skills) and $(v)$ make responsible decisions (responsible decision-making).

For example, in the strategy of AfL - engineering good classroom discussions, teachers would ask questions to elicit students' understanding. Oliveira (2010) broadly describes teacher questioning as a social activity in forming identities and relationships and a cognitive activity in developing students' thinking. The social activity aspect is where the teacher has conversations that build rapport with their students by creating warm relationships and a safe environment for learning (Rich \& Schachter, 2012). Teachers do not discuss the subject matter outside of students' interests but connect the subject matter with personal experiences in a story-telling manner and encourage students to be engaged in the discourses. Teachers must be able to establish and maintain positive relationships (relationship skills). Thus, when these teachers ask questions, students can answer them honestly and without fear of being wrong. In addition, teachers can get valuable feedback about their students' (mis)conceptions through these discourses, giving them better opportunities to modify their teaching to suit their students' learning needs (Darling-Hammond et al., 2020).

When teachers provide feedback (an AfL strategy), teachers aspire to generate accurate student learning decisions (Wiliam \& Leahy, 2015). In the feedback process, the teacher usually recognises when in conversations with their students what their ideas are and how to respond to help students construct scientifically accepted arguments (Cowie et al., 2018). However, they must take into consideration students' personalities. Some students require more time to understand the input, and teachers need to be patient (Ryan \& Henderson, 2018). There would be students who feel that they had failed because of the gaps in the learning. Teachers must motivate and show students that they can easily overcome these gaps if they persist and are determined to succeed. When teachers do so, they could be considered as having responsible decision-making.

When teachers conduct peer assessment, it involves providing feedback and commenting on peers' work. Teachers must teach students how to communicate well. Often peers give input in an intonation that may sound hurtful even though it is constructive, or students do not value what their peers have to offer (Rotsaert et al., 2017). Teachers ought to create social awareness so that students are sensitive to talking and listening to their peers. Teachers can scaffold students to provide accurate feedback and guide them to speak politely, respectfully, and collaboratively. Table 1 shows AfL strategies and the SEC that teachers could acquire to enhance their AfL practices. 
Table 1: The Strategies of AfL Strategies and the Accompanying Teachers' SEC

\begin{tabular}{|c|c|c|c|}
\hline \multicolumn{2}{|c|}{ Assessment for Learning (AfL) Strategies } & \multicolumn{2}{|c|}{$\begin{array}{l}\text { Social and Emotional Competencies (SEC) } \\
\text { That Complement AfL Strategies }\end{array}$} \\
\hline $\begin{array}{l}\text { Sharing } \\
\text { Learning Goals }\end{array}$ & $\begin{array}{l}\text { Teachers share learning } \\
\text { outcomes/ Teachers show } \\
\text { and discuss the success } \\
\text { criteria with students }\end{array}$ & $\begin{array}{l}\text { Teachers help students to manage } \\
\text { the stress, regulate their emotions } \\
\text { about their learning and help them to } \\
\text { be motivated }\end{array}$ & Self-management \\
\hline $\begin{array}{l}\text { Engineering } \\
\text { Good } \\
\text { classroom } \\
\text { discussions }\end{array}$ & $\begin{array}{l}\text { Teachers develop suitable } \\
\text { quality tasks and ask high } \\
\text { order thinking questions }\end{array}$ & $\begin{array}{l}\text { Teachers prepare tasks with } \\
\text { consideration of students' interests. } \\
\text { Build a warm rapport and safe } \\
\text { learning environment, so students } \\
\text { are free to give comments and } \\
\text { suggestions. }\end{array}$ & Relationship Skills \\
\hline $\begin{array}{l}\text { Constructive } \\
\text { Feedback }\end{array}$ & $\begin{array}{l}\text { Discuss students' strengths } \\
\text { and weaknesses and } \\
\text { provide content-accuracy } \\
\text { feedback }\end{array}$ & $\begin{array}{l}\text { Understand students' personalities } \\
\text { and are aware of the manner to } \\
\text { provide feedback (having patience) }\end{array}$ & $\begin{array}{l}\text { Responsible } \\
\text { Decision-making }\end{array}$ \\
\hline $\begin{array}{l}\text { Peer- } \\
\text { assessment }\end{array}$ & $\begin{array}{l}\text { Teachers create } \\
\text { opportunities for students } \\
\text { to use peers' as learning } \\
\text { resources. }\end{array}$ & $\begin{array}{l}\text { Teach students to be sensitive } \\
\text { to peers' feelings - being polite, } \\
\text { modelling practical speaking } \\
\text { and listening skills, and working } \\
\text { collaboratively. }\end{array}$ & Social Awareness \\
\hline $\begin{array}{l}\text { Self- } \\
\text { assessment }\end{array}$ & $\begin{array}{l}\text { Techniques to encourage } \\
\text { students to do self- } \\
\text { assessment like 'exit tickets.' }\end{array}$ & $\begin{array}{l}\text { Teach students to be honest about } \\
\text { their self-evaluation and remind } \\
\text { students to be optimistic about their } \\
\text { assessment. }\end{array}$ & Self-awareness \\
\hline
\end{tabular}

Source: Ryerse \& Ark (2018)

Thus, creating a safe learning environment when implementing "key strategies" of AfL can get their students to take ownership and control of their learning and at the same time improve their cognitive competencies (Haertel et al., 2008; Willis, 2010). Since AfL is associated with enhancing knowledge, we investigated how science teachers' SEC influences the implementation of AfL strategies in this study (Ryerse \& Ark, 2018).

\section{The Context of the Study}

Malaysia had introduced a school-based assessment initiative known as Pentaksiran Berasaskan Sekolah (School-based Assessment, hereafter referred to as SBA), which was implemented in stages, beginning with Year 1 (primary education) in 2011 and Year 7 (secondary), the first year of secondary school, from 2012. This policy was a response to the sufficient literature that points to the drawbacks of the external public examinations (Berry, 2011). SBA is a holistic assessment that considers the cognitive, affective, and psychomotor aspects of learning within the framework of the National Education Philosophy and national curriculum (Ministry of Education, MOE, 2019). According to the Malaysia Education Blueprint 2013-2025, the purpose of SBA is to emphasise the importance of assessment in monitoring student progress in learning rather than merely relying on scores or grades from centralised examinations (MOE, 2013). This school-based assessment initiative was based on the principles of AfL, which gave teachers the autonomy to design forms of assessment tailored for their teaching-learning needs; to use feedback from assessment to diagnose learning problems and to recalibrate their teaching strategies (Kamal \& Rahman, 2006; Md-Ali et al., 2015). In this study, the focus is the SEC of the teachers and how these competencies influence their AfL practices. 


\section{Methodology}

In the main study, 153 teachers teaching the four core subjects (Mathematics, Science, Bahasa Malaysia, and English language) participated. They were observed via video recordings for three lessons of their choice. Video data were collected to gain an insight into teachers' AfL practices. The teachers' AfL practices were measured from the video recordings, then analysed using a priori coding framework called Malaysian Teachers' Assessment Practices Instrument (or MTAPI). The analysis of the video data using MTAPI was focused on how the observed practice most resembled established good practices, as defined by AfL literature (Black \& Wiliam, 2006, 2009; Heritage, 2013; Wiliam, 2009, 2018; Wiliam \& Thompson, 2007; Wylie, Lyon \& Mavronikolas, 2008).

The dimensions in MTAPI included (i) Sharing learning target, (ii) Engineering good classroom discussions, (iii) Descriptive feedback, and (iv) Peer assessment. Each teacher's practice level was coded as 'Unsatisfactory', 'Basic', 'Proficient', and 'Distinguished' (Sathasivam et al., 2019). For example, a teacher who predominantly provide evaluative feedback is coded as 'Unsatisfactory' for Descriptive Feedback Dimension and has the descriptors: a. Feedback is absent or of poor quality; mostly evaluative and $b$. Feedback is not oriented towards learning objectives. Table 2 shows the Descriptive Feedback Dimension and its descriptors. Validity and reliability procedures for video data coding included training, establishing a pair-coding system and a quantitative post hoc approach. For details of how this process was developed, please refer to Tee et al. (2016).

The analysis from the main study showed that the teachers' AfL practices were so skewed that most of the teachers' AfL practices were at the Basic and Unsatisfactory levels. In the main study, 92.6\% of the teachers were assigned to the Unsatisfactory level for the Dimension Peer Assessment. Among the 153 participants, there were 30 science teachers. However, when scrutinised, it was found that only two teachers were at the Basic level, and the rest were at the Unsatisfactory level (Sathasivam et al., 2019). Thus, this study placed the lens on two teachers, one randomly picked from the 'Unsatisfactory' and 'Basic' levels, respectively, to compare if the differences in SEC among these teachers led to the differences in their AfL performance-rating level. The two teachers were chosen, Tharini and Aishah (pseudo names), based on their AfL practices' performance ratings. Tharini's overall AfL practices were at the Basic level, considered as one of the 'outliers' in terms of AfL practices among the science teachers. In contrast, Aishah's AfL practices were rated Unsatisfactory and represent the typical Malaysian science teachers' AfL assessment practices.

Table 1 was used as a framework for coding the various AfL practices and teachers' SEC. For example, when conducting their classroom discussions, the teacher attempted to build a warm rapport and safe learning environment for the students so that they felt free to give comments and suggestions. If there was active participation among the students, it might be said that the teacher did exhibit some relationship skills.

\section{Findings}

The findings showed that both teachers did not practice all the five AfL strategies proposed by Wiliam and Thompson (2007). Therefore, only three strategies would be discussed-Engineering good classroom Discussions, Constructive feedback, and Peer assessment. We are aware that Tharini was not implementing these AfL strategies at the 'Distinguished' level. However, we aimed to explore if the social and emotional support during the classroom discourses was the reason for the differences in our scoring rubric (MTAPI framework) for the implementation of AfL. The video recordings showed that both teachers did not explicitly discuss the learning target with their students but simply stated what they would be learning for that lesson. The differences between teachers were that Tharini began her class with a smile and asked her students if they were ready to study. In contrast, Aishah expressed annoyance when some of her students came in late and began the lesson with irritation. The following sections discuss three dimensions of the AfL: Engineering Good Classroom Discussion, Constructive Feedback and Peer Assessment. 
Table 2: Example of MTAPI for the Dimension Descriptive Feedback

\begin{tabular}{|c|c|c|c|c|c|c|}
\hline & Unsatisfactory & Basic & & Proficient & & Distinguished \\
\hline $\begin{array}{l}\text { Descriptive } \\
\text { Feedback }\end{array}$ & $\begin{array}{l}\text { a. } \begin{array}{l}\text { Feedback } \\
\text { is absent } \\
\text { or of poor } \\
\text { quality, mostly } \\
\text { evaluative. }\end{array} \\
\text { b. Feedback is } \\
\text { not oriented } \\
\text { towards } \\
\text { learning } \\
\text { objectives. }\end{array}$ & $\begin{array}{l}\text { a. Feedback is } \\
\text { given in a } \\
\text { general way. } \\
\text { b. Feedback is } \\
\text { limited on } \\
\text { the lesson's } \\
\text { learning } \\
\text { objectives. } \\
\text { c. Feedback is } \\
\text { not uniformly } \\
\text { specific towards } \\
\text { learning } \\
\text { objectives. }\end{array}$ & $\begin{array}{l}\text { b. } \\
\text { c. } \\
\text { d. }\end{array}$ & $\begin{array}{l}\text { Feedback is not } \\
\text { only limited on the } \\
\text { lesson's learning } \\
\text { objectives. } \\
\text { Oral feedback } \\
\text { provided } \\
\text { appears planned, } \\
\text { constructive, } \\
\text { informative, } \\
\text { regular and } \\
\text { frequent. } \\
\text { Written or oral } \\
\text { feedback provides } \\
\text { description of the } \\
\text { student's strengths } \\
\text { and weaknesses. } \\
\text { Written or oral } \\
\text { feedback provides } \\
\text { description of } \\
\text { how students can } \\
\text { improve their } \\
\text { work and make } \\
\text { the next step. } \\
\text { Feedback includes } \\
\text { specific and timely } \\
\text { guidance, at least } \\
\text { for groups of } \\
\text { students. }\end{array}$ & e. & $\begin{array}{l}\text { Feedback is not } \\
\text { only limited on the } \\
\text { lesson's learning } \\
\text { objectives. } \\
\text { Oral feedback } \\
\text { provided } \\
\text { appears planned, } \\
\text { constructive, } \\
\text { informative, regular } \\
\text { and frequent. } \\
\text { Written or oral } \\
\text { feedback provides } \\
\text { description of the } \\
\text { student's strengths } \\
\text { and weaknesses. } \\
\text { Written or oral } \\
\text { feedback provides } \\
\text { description of } \\
\text { how students can } \\
\text { improve their work } \\
\text { and make the next } \\
\text { step. } \\
\text { Feedback includes } \\
\text { specific and timely } \\
\text { guidance, at least } \\
\text { for groups of } \\
\text { students. } \\
\text { The students are } \\
\text { given time to } \\
\text { reflect, respond } \\
\text { and plan their next } \\
\text { actions in the light } \\
\text { of the feedback } \\
\text { given. }\end{array}$ \\
\hline
\end{tabular}

Source: Sathasivam et al (2019)

\section{Engineering Good Classroom Discussion}

In Engineering Good Classroom Discussion, teachers must develop suitable quality tasks and ask high order thinking questions. Teachers must prepare these tasks with consideration of students' interests. In addition, teachers are considered to have relationship skills to build a warm rapport and safe learning environment, so students are free to give comments and suggestions.

In Aishah's class, she began her lesson by asking questions about the content taught in the previous class. As she asked them the question - What is the definition of density, many of her students remained silent and had typically kept their heads slightly lowered. When Aishah's students did not respond to her question, she immediately asked another more close-ended question. 
Aishah : Objects with low density are the objects that will sink or float?

Ss : Float

Since this question was much easier to answer, the students were able to answer the question. Aishah seemed satisfied with the answer and had moved on with her lesson. As she continued questioning her students about the topic she was teaching, many students appeared to be confused. However, Aishah seemed very focused on the content matter and asked students' what factors could influence density. No student responded to her question. Aishah looked around the classroom expecting an answer until a student answered meekly.

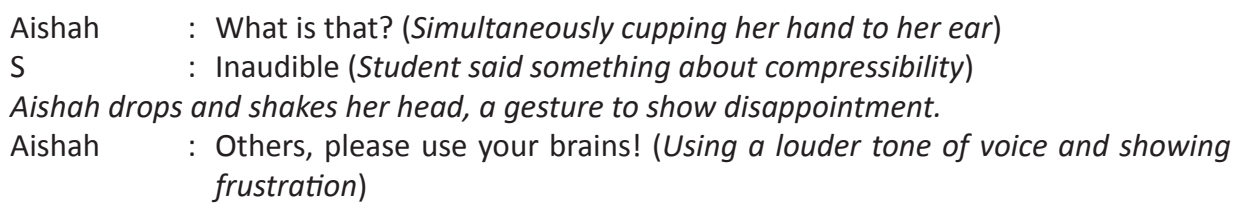

Aishah's AfL practices on asking high-quality questions were not successful. Aishah asked lowlevel questions and seemed more interested in eliciting the correct answers from her students instead of getting to know their understanding of the lesson. Though Aishah asked her students questions, she did not seem interested to help them overcome their difficulties, even though there were clear indications that her students did not understand the topic well. She had not built a warm rapport and safe learning environment, primarily when she used a louder voice and showed frustration when her students could not answer her questions. The students' body language and the lack of response may indicate that they do not feel free to state their lack of understanding.

When Tharini was about to start her lesson, a student reminded her about the previous day homework that she had given them. Tharini smiled and said, 'oh whoa...' (showing she was pleased that her students reminded her). Tharini had asked her students to find out if a rock was renewable or not. Many of her students were eager to give their answers. They were putting up their hands and saying Me! Me! Tharini smiled and put her finger to her lips (telling them to be patient).

\footnotetext{
Tharini : Wait, wait, who found out about the rock. (Many students put up their hands). I want to know how you found out...from which website.

S1 : I asked my brother-in-law.

S2 : Teacher, I found it at WikiAnswers.

Tharini : Oh, WikiAnswers. Ok, wait. Do you all remember the question? Is a rock...is it renewable or not? Turn around so your friends can hear you. (Speaking to S2)

S2 : Rock is renewable but takes a long period of time to renew. Rock cannot be renewed in a short period of time.

Tharini : Can you all hear that? Ok, his answer, which is WikiAnswer, says that rock is renewable, but it takes a long time to be renewed (showing gesture with arms spread out wide). Ok, one answer, thank you.

Similarly, she received answers from other students and repeated them to hear what their friends had found out.
}

Tharini provided her students with an open-ended question. She allowed her students to take responsibility for their learning as they explored and found the information by themselves. Tharini's students felt valued because Tharini listened to them and repeated their answers, showing them that she was paying attention to their thoughts and ideas. Tharini even asked how and where the students had their answers, indicating her interest in their learning process. Tharini's classroom 
environment was warm and friendly, and students felt safe to give their answers as many of them were willing to answer by putting up their hands eagerly. She also made a point to get her students to speak to their friends, indicating the importance of speaking and hearing about the content with peers. When Tharini can receive various answers from her students, she has valuable information about her students' learning.

\section{Constructive Feedback}

In this AfL strategy, teachers must discuss students' strengths and weaknesses and provide contentaccuracy feedback. Teachers with SEC would do so by understanding students' personalities and are aware of the manner to provide feedback so that students are more receptible to receive that feedback. Teachers must have patience when giving feedback. The teachers' SEC would be responsible for decision-making.

Aishah's AfL practices on oral feedback appear to be evaluative, where when students could not answer the question, she seems to belittle the student. For example, when a student answered one of the questions wrongly, Aishah repeated the wrong answer a few times but louder.

Aishah : point five? point five? POINT FIVE? Please read the question well. Others, what is the answer? Other students answer. Yes, 5.5. Your answer after this will be problematic, ok? (Informing the student).

Aishah did not seem to have the patience to explain explicitly to her students where and why she had gotten the wrong answer. In another classroom discourse, Aishah's student had given her the correct answer. So Aishah asked that student to explain how she arrived at her response. When the student could not justify how she got the answer, Aishah did not probe further to clarify the student's difficulties in the learning process. Instead, Aishah immediately provided her with the solution.

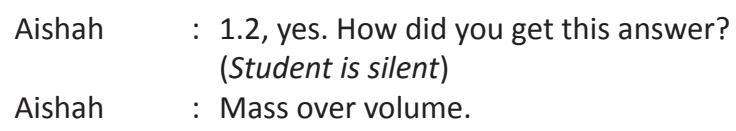

Aishah's AfL feedback practices were evaluative. She was more interested in obtaining or giving the correct answer. There were no words of encouragement or motivation. She did not show any patience when students were struggling to answer. Instead, she was upset when they gave the wrong answers. Moreover, Aishah did not attempt to show her students where they had gone wrong and how they may move on with their learning. Her current feedback practices did not give her students the chance to enhance their knowledge, and these students are likely to resort to rote memorisation.

In contrast, Tharini provided feedback that explained and incorporated answers from her students. After receiving responses such as 'teacher, it is non-renewable, but I don't know why', 'rock is a geothermal energy, and it is renewable', and 'renewable', she asked the students if they wanted to know the answer. Tharini provided examples from her students' responses to summarise what was discussed.
Tharini : It's both - renewable and non-renewable. Tharini smiles, and some of her students smile and laugh.
Tharini $\quad:$...It's also non-renewable because, like Ryan said just now, it takes a long time, a super long, a super, duper, super, duper, luper long time for it to be renewed. (Putting hands apart to imply a long period of time). Does that make sense to you?... And if you ask me, I will go with non-renewable because...

When students provided her with their answers, Tharini acknowledged all her students' answers. She was patient and listened before she delivered her feedback. She valued what each 
student had said. Thus, Tharini accepted various answers and acknowledged these answers before she decided to give her point of view about the subject matter - 'if you ask me, I will go with nonrenewable'.

\section{Peer-Assessment}

In this AfL strategy, the teacher must purposefully create opportunities for students to use peers' as learning resources. In the interactions between peers, teachers with SEC would also teach about social awareness. Teachers would point out how to be sensitive to peers' feelings - being polite, modelling practical speaking and listening skills, and working collaboratively.

Aishah asked her students a question when she noticed that one of her students was talking to his friend. She pointed to that student and told him that the next question would be for him. Aishah punished students for speaking, and thus, peer talk was discouraged in her classes.

On the other hand, Tharini asked her students to work in groups to create a short story to show their understanding of the concept of heat. She then made them share their ideas with the class. One pair shared the following example.

Tharini : Ok. You can hear this. This is really funny. Let's turn behind (So the girls can face their friends). Ok, so listen to this.

S1 : A guy in WWE (World Wrestling Entertainment) and Sugen (their classmate). A normal person comes and hugs both of them; the guy who hugs the WWE person will have more heat. ... Like he is bigger. (Students were laughing)

Tharini : (Smiling) Her point is - bigger people have more heat. We should do this experiment (Playfully)

As seen in Tharini's class, the learning environment was safe as students trusted each other and were willing to use their friend's name (Sugen) in their example. In addition, Tharini up-took her students' interest in learning and did not belittle or scold them when they provided examples that some teachers could consider as bad-mannered.

Though there was no clear evidence of peer assessment, Tharini had initiated ideas of peer assessment when she asked her students to listen to their friends' stories and see if the story was funny and interesting. By allowing her students to work in groups and create their own stories, they would have evaluated the quality of their work before presenting it to their classmates. By allowing her students to participate in the classroom actively, Tharini turned the learning classroom discourses into more meaningful and folksy conversations that enable students to relate the new learning material to their personal experiences. In contrast, Aishah's lessons revealed fewer students' voices, and there were no student-student interactions. Student-student interactions are a prerequisite for peer assessment and are the heartbeat of AfL practices, and these components were absent in Aishah's lessons.

\section{Discussion and Conclusion}

The findings of this study showed that Tharini was more successful when compared to Aishah in implementing AfL strategies. Bearing in mind, Tharini was placed at the Basic level in the MTAPI framework as there were many aspects of the AfL strategies she was not implementing well. For example, she did not explicitly share the learning target as suggested in the literature (Black \& Wiliam, 2006, 2009; Heritage, 2013; Wiliam, 2009, 2018; Wiliam \& Thompson, 2007; Wylie, Lyon \& Mavronikolas, 2008). Moreover, when there were hints of Tharini using peers as resources for learning, these practices did not progress to the proficient level as she did not encourage her students to evaluate their peers' work. It was Tharini who decided which students' example was good. She did not involve other students and asked them how it was related to the content matter or how they may improve the story to make it more relevant to the topic under discussion. 
The MTAPI framework placed Tharini's practices as more successful when compared to Aishah's practices. In terms of engineering good classroom discussions, there were hints of her creating learning opportunities for her students took responsibility for their learning. She did not constantly spoon-feed her students with information (Sach, 2012). Tharini also created a sense of belonging through her calm and witty approach during her lessons, inducing humour and making the class safe for her students to experiment with new and innovative ideas (Willis, 2010). Tharini had, at instances during her lessons, inspired her students to heed to their peers' thoughts and ideas, and encouraged teamwork, cooperation and trust among her students (CASEL, 2019; Taylor \& Parsons, 2011). She provided an environment where her students felt support from her, which made them feel more motivated and actively involved in the learning process (Hen \& Goroshit, 2016). Thus, by creating a more social and emotional learning environment, Tharini exhibited a more successful AfL implementation.

Aishah did not seem to encourage conversation in her class, whether it was peer-to-peer or teacher-student. According to Oliveira (2010), good classroom discussions are an important social activity in forming good rapport with students and a cognitive activity that helps students develop their thinking. However, an environment such as this makes students feel unsafe to express themselves, hence finding Aishah's students less engaging in learning. Furthermore, when teachers such as Aishah do not provide good feedback, students will struggle to understand and identify aspects of learning where they are not grasping (Darling-Hammond et al., 2020).

Aishah is still very comfortable with the hierarchical teacher-student relationship (Hofstede et al., 2010; Marshall \& Drummond, 2006). These hierarchical teacher-student relationships do not allow students to receive feedback that can move their learning forward and does not allow them to take responsibility for their learning; these two actions are an antithesis to AfL principles (Hattie \& Timperley, 2007; Heritage, 2013). Aishah can be seen as a teacher who operates in high powerdistant culture, as Hofstede, Hofstede and Minkov (2010) mentioned. She probably sees herself as a knowledge keeper and does not feel the need to change.

Therefore, this study demonstrated the importance of good classroom discussions, constructive feedback, and peer assessment for successful AfL implementation if accompanied by the teacher's effort to encourage active learning participation in the classroom. However, AfL implementation requires both teacher and student to engage in multifaceted practices. Therefore, there is a need to educate teachers not only on the strategies of AfL but also on the creation of social and emotional learning environments to boost the positive effects of AfL (Pryor \& Crossouard, 2008, p. 6). In line with this, teacher education and teacher development programmes should help pre-and in-service teachers to create and marry AfL strategies with content matter and, at the same to create classroom cultures that are socially and emotionally conducive (Ryerse \& Ark, 2018). In addition, assisting teachers in developing positive and engaging learning relationships with their students (Willis, 2011) can lead to more effective implementation of AfL strategies and, finally, the success of school-based assessment that many educational systems inspire to achieve. This is to help achieve the aim of the Ministry of Education in Malaysia to encourage more AfL in the classroom (MOE, 2019).

Researchers have conceptualised $\mathrm{AfL}$ as a collaborative process involving teachers and peers and how this may affect student learning. AfL and social and emotional learning have been often treated separately by researchers and practitioners, but both are necessary to build students' competencies (Ryerse \& Ark, 2018). To date, researchers have investigated teachers' cognitive and emotional resources mostly in separate studies stemming from different theoretical traditions, neglecting a possible relevance for effective teaching, especially for the implementation of AfL strategies (Steinberg, 2008; Wiliam, 2018). In this study, we combine both perspectives. Although cognitive resources such as professional knowledge are crucial for effective instruction, we argue that teachers will profit from this only if they possess sufficient emotional resources due to the complexity of teaching. Teachers' SEC help students to communicate with others persist in challenging assignments, comply with classroom norms, and find the motivation to achieve. 
Teachers' ability to express and understand their own and students' emotions is essential for today's teaching profession. Teachers must manage their students' challenges faced in emotional activities that cover aspects of motivation, abilities, and personal backgrounds (Bahia et al., 2013). Therefore, it is crucial to equip them with the skills that will ease their daily activities. This is in line with one of the aspirations of the Malaysia Education Blueprint 2013-2025 to instil strong ethics, emotions and spirituality in students that will help them be resilient in facing life's challenges (MOE, 2013). It is also important to mention that the cultural context and the subject teachers teach should be considered because they can play an important role when considering teachers' emotions (Sutton \& Wheatley, 2003). Research shows that teachers acknowledge the importance of emotions in transferring knowledge because they feel students are more motivated if they use positive emotions in their teaching (Weissberg, 2016).

Thus, allowing active participation of students in their learning, developing warm and sustainable relationships, and identifying and responding to individual needs have shown to be significantly essential factors in learning (Humphrey, 2013; Osher et al., 2020; Pianta, Vandergrift, Houts \& Morrison, 2008). A classroom environment that considers the importance of students' emotional well-being provides a conducive learning atmosphere for students to strive and grow positively.

\section{Note:}

1 The authors reported no potential conflict of interest. This work was supported by University Malaya Research Grant (UMRG) Project Number RP004-13SBS.

\section{References}

Andrade, H.L. \& Cizek, G.J. (2010). Handbook of Formative Assessment. New York: Routledge. doi:10.4324/9780203874851

Aspelin, J. (2012). How do relationships influence student achievement? Understanding student performance from a general, social psychological standpoint. International Studies in Sociology of Education, 22(1), pp. 41-56. doi:10.1080/09620214.2012.680327

Bahia, S., Freire, I., Amaral, A. \& Estrela, M. T. (2013). The emotional dimension of teaching in a group of Portuguese teachers. Teachers and teaching, 19(3), pp. 275-292. doi:10.1080/1354 0602.2012.754160

Berry, R. (2011). Assessment trends in Hong Kong: seeking to establish formative assessment in an examination culture. Assessment in Education: Principles, Policy \& Practices, 18(2), pp. 199211. doi:10.1080/0969594X.2010.527701

Black, P. \& Wiliam, D (1998). Assessment and Classroom Learning. Assessment in Education: Principles, Policy \& Practice, 5(1), pp. 7-74. doi:10.1080/0969595980050102

Black, P. \& Wiliam, D. (2003). In praise of educational research: Formative assessment. British Educational Research Journal, 29(5), pp. 623-637. doi:10.1080/0141192032000133721

Black, P. \& Wiliam, D. (2006). Developing a theory of formative assessment. In J. Gardner (Ed.), Assessment and Learning. London: Sage, pp. 81-100.

Black, P. \& Wiliam, D. (2009). Developing the theory of formative assessment. Educational Assessment, Evaluation and Accountability, 21(1), pp. 5-31. doi:10.1007/s11092-008-9068-5

CASEL (2019), Core SEL Competencies. Available at: https://casel.org/core-competencies/ [Accessed 17 March 2019].

Chen, C.H. (2008). Why do teachers not practice what they believe regarding technology integration? The Journal of Educational Research, 102(1), pp. 65-75. doi:10.3200/JOER.102.1.65-75

Collie, R.J. (2017). Teachers' social and emotional competence: Links with social and emotional learning and positive workplace outcomes. In E. Frydenberg, A.J. Martin, \& R.J. Collie 
(Eds.). Social and Emotional Learning in Australia and the Asia-Pacific. Singapore: Springer. doi:10.1007/978-981-10-3394-0_9, pp.167-184.

Cornelius-White, J. (2007). Learner-centred teacher-student relationships are effective: A metaanalysis. Review of Educational Research, 77(1), pp. 113-143. doi:10.3102/003465430298563

Cowie, B., Harrison, C. \& Willis, J. (2018). Supporting teacher responsiveness in assessment for learning through disciplined noticing. The Curriculum Journal, 29(4), pp. 464-478. doi:10.1080/09585176.2018.1481442

Darling-Hammond, L., Flook, L., Cook-Harvey, C., Barron, B. \& Osher, D. (2020). Implications for educational practice of the science of learning and development. Applied Developmental Science, 24(2), pp. 97-140. doi:10.1080/10888691.2018.1537791

DeLuca, C., Luu, K., Sun, Y. \& Klinger, D. A. (2012). Assessment for learning in the classroom: Barriers to implementation and possibilities for teacher professional learning. Assessment Matters, 4, pp. 5-29. doi:10.18296/am.0104

Dori, Y. J. (2003). From nationwide standardised testing to school-based alternative embedded assessment in Israel: Students' performance in the Matriculation 2000 project. Journal of Research in Science Teaching, 40(1), pp. 34-52. doi:10.1002/tea.10059

Eccles, J. S. \& Roeser, R. W. (2011). Schools as developmental contexts during adolescence. Journal of Research on Adolescence, 21(1), pp. 225-241. doi:10.1111/j.1532-7795.2010.00725.x

Fraire, M., Longobardi, C., Prino, L. E., Sclavo, E., \& Settanni, M. (2013). Examining the student-teacher relationship scale in the Italian context: a factorial validity study. Electronic Journal of Research in Educational Research, 11, pp. 649-664. doi:10.1037/t72386-000

Haertel, E., Moss, P., Pullin, D. \& Gee, J. (2008). Introduction. In P. Moss, D. Pullin, J. Gee, E. Haertel \& L. Jones (Eds.), Assessment, Equity, and Opportunity to Learn. New York: Cambridge University Press, pp. 1-16. doi:10.1017/СВ09780511802157.003

Hargreaves, A. (1998). The emotional practice of teaching. Teaching and Teacher Education, 14(8), pp. 835-854. doi:10.1016/S0742-051X(98)00025-0

Hattie, J. \& Timperley, H. (2007). The Power of Feedback. Review of Educational Research, 77(1), pp. 81-112. doi:10.3102/003465430298487

Hayward, L., \& Spencer, E. (2010). The complexities of change: Formative assessment in Scotland. Curriculum Journal, 21(2), pp. 161-177. doi:10.1080/09585176.2010.480827

Hen, M. \& Goroshit, M. (2016). Social-emotional competencies among teachers: An examination of interrelationship. Cogent Education, 3(1), 1151996. doi:10.1080/2331186X.2016.1151996

Heritage, M. (2010). Formative Assessment: Making it Happen in the Classroom. Thousand Oaks, CA: Corwin Press.

Heritage, M. (2013). Formative Assessment in Practice: A Process of Inquiry and Action. Cambridge, MA: Harvard Education Press.

Heritage, M., Kim, J., Vendlinski, T. \& Herman, J. (2009). From evidence to action: A seamless process in formative assessment? Educational Measurement: Issues and Practice, 28(3), pp. 24-31. doi:10.1111/j.1745-3992.2009.00151.x

Hofstede, G., Hofstede, G. J. \& Minkov, M. (2010). Cultures and Organisations: Software of the Mind. New York: McGraw-Hill.

Hopfenbeck, T.N., Petour, M.T.F. \& Tolo, A. (2015). Balancing tensions in educational policy reforms: large-scale implementation of assessment for learning in Norway. Assessment in Education: Principles, Policy \& Practice, 22(1), pp. 44-60. doi:10.1080/0969594X.2014.996524

Humphrey, N. (2013). Social and Emotional Learning: A Critical Appraisal. London: Sage. doi:10.4135/9781446288603

Janssen, F. J. J. M., Westbroek, H. B. \& Doyle, W. (2015). Practicality studies: How to move from what works in principle to what works in practice. Journal of the Learning Sciences, 24(1), pp. 176-186. doi:10.1080/10508406.2014.954751 
Jennings, P. A., Frank, J. L., Snowberg, K. E., Coccia, M. A., \& Greenberg, M. T. (2013). Improving classroom learning environments by Cultivating Awareness and Resilience in Education (CARE): Results of a randomized controlled trial. School Psychology Quarterly, 28(4), pp. 374-390. doi:10.1037/spq0000035

Jennings, P.A. \& Greenberg, M.T. (2009). The prosocial classroom: Teacher social and emotional competence in relation to student and classroom outcomes. Review of Educational Research, 79(1), pp. 491-525. doi:10.3102/0034654308325693

Kamal, R. Z., \& Rahman, S. A. (2006). Sistem Peperiksaan Diubah: Tumpu Penilaian Seimbang Kemahiran Pelajar Selain Akademik [Changes in examination system: Focus on a balanced evaluation of students' skills other than academic]. Utusan Malaysia (18 May 2006), p.7.

Klenowski, V. (2011). Assessment for learning in the accountability era: Queensland, Australia. Studies in Educational Evaluation, 37(1), pp. 78-83. doi:10.1016/j.stueduc.2011.03.003

Leahy, S. \& Wiliam, D. (2012). From teachers to schools: Scaling up professional development for formative assessment. In J. Gardner (ed), Assessment and Learning. London: Sage, pp. 49-71. doi:10.4135/9781446250808.n4

Lloyd, M.H., Kolodziej, N.J. \& Brashears, K.M. (2016). Classroom discourse: An essential component in building a classroom community. School Community Journal, 26(2), pp. 291-304.

Marshall, B. \& Drummond, J. M. (2006). How teachers engage with Assessment for Learning: lessons from the classroom. Research Papers in Education, 21(2), pp. 133-149. doi:10.1080/02671520600615638

Md-Ali, R., Veloo, A. \& Krishnasamy, H. N. (2015). Implementation of school-based assessment: The experienced teachers' thoughts. Australian Journal of Basic and Applied Sciences, 9(18), pp. 72-78.

Ministry of Education Malaysia [MOE]. (2013). Malaysia Education Blueprint 2013-2025 (Preschool to post-secondary education). Putrajaya: Ministry of Education Malaysia.

Ministry of Education Malaysia [MOE]. (2019). Panduan Pelaksanaan Pentaksiaran Bilik Darjah. Edisi Kedua (Classroom Assessment Implementation Guide). Putrajaya: Ministry of Education Malaysia.

Oliveira, A. W. (2010). Improving teacher questioning in science inquiry discussions through professional development. Journal of Research in Science Teaching, 47(4), pp. 422-453. doi:10.1002/tea.20345

Osher, D., Cantor, P., Berg, J., Steyer, L. \& Rose, T. (2020). Drivers of human development: How relationships and context shape learning and development. Applied Developmental Science, 24(1), pp. 6-36. doi:10.1080/10888691.2017.1398650

Pianta, R., Belsky, J., Vandergrift, N., Houts, R. \& Morrison, F. (2008). Classroom effects on children's achievement trajectories in elementary school. American Educational Research Journal, 45(2), pp. 365-397. doi:10.3102/0002831207308230

Poplin, M., \& Weeres, J. (1994). Voices from the Inside: A Report on Schooling from Inside the Classroom. Claremont, CA: Institute for Education in Transformation at the Claremont Graduate School.

Pryor, J. \& Crossouard, B. (2008). A sociocultural theorisation of formative assessment. Oxford Review of Education, 34(1), pp. 1-20. doi:10.1080/03054980701476386

Rich, Y., \& Schachter, E.P. (2012). High school identity climate and student identity development. Contemporary Educational Psychology, 37(3), pp. 218-228. doi:10.1016/j.cedpsych.2011.06.002

Rogers, C. R. (1969). Freedom to Learn. Columbus, OH: Charles E. Merrill.

Rogers, C. R. (1983). Freedom to Learn for the '80s. Columbus, OH: Charles E. Merrill.

Rotsaert, T., Panadero, E., Estrada, E. \& Schellens, T. (2017). How do students perceive the educational value of peer assessment in relation to its social nature? A survey study in Flanders. Studies in Educational Evaluation, 53, pp. 29-40. doi:10.1016/j.stueduc.2017.02.003 
Ryan, T. \& Henderson, M. (2018). Feeling feedback: Students' emotional responses to educator feedback. Assessment \& Evaluation in Higher Education, 43(6), pp. 880-892. doi:10.1080/02 602938.2017.1416456

Ryerse, M. \& Ark, T.V. (2018). Social and Emotional Learning Skills are essential to Formative Assessment Practices. Available at https://www.gettingsmart.com/2018/03/formativeassessment-and-social-and-emotional-skills/ [Accessed 13 May 2020]

Sach, E. (2012). Teachers and testing: an investigation into teachers' perceptions of formative assessment. Educational Studies, 38(3), pp. 261-276. doi:10.1080/03055698.2011.598684

Sathasivam, R.V., Samuel, M., Norjoharudden, M.N., Tee, M.Y. \& Leong, K.E. (2019). Assessment for learning: Espoused and enacted practices of Malaysian teachers. Pertanika Journal of Social Sciences and Humanities, 27(T2), pp. 47-62.

Schneider, C., \& Randel, B. (2010). Research on characteristics of effective professional development programs for enhancing educators' skills in formative assessment. In H. Andrade \& G. Cizek (Eds.), Handbook of Formative Assessment. New York, NY: Routledge, pp. 251-276.

Shepard, A. L. (2019). Classroom assessment to support teaching and learning. The ANNALS of the American Academy of Political and Social Science, 683(1), pp. 183-200. doi:10.1177/0002716219843818

Steinberg, C. (2008). Assessment as an "emotional practice". English Teaching: Practice and Critique, 7(3), pp. 42-64.

Sutton, R. E. \& Wheatley, K. F. (2003). Teachers' emotions and teaching: A review of the literature and directions for future research. Educational Psychology Review, 15, pp. 327-358. doi:10.1023/A:1026131715856

Swaffield, S. (2011). Getting to the heart of authentic Assessment for Learning. Assessment in Education: Principles, Policy and Practice, 18(4), pp. 433-449. doi:10.1080/096959 4X.2011.582838

Taylor, L. \& Parsons, J. (2011). Improving Student Engagement. Current Issues in Education, 14 (1) Available at: http://cie.asu.edu/ojs/index.php/cieatasu/article/viewFile/745/162 [Accessed 13 May 2021]

Tee, M. Y., Samuel, M., Norjoharudden, M. N. \& Nadarajan, S. (2016). A methodological approach for researching national classroom practices. Journal of International and Comparative Education, 5(1), pp. 1-17. doi:10.14425/jice.2016.5.1.01

Weissberg, R. (2016). Why Social and Emotional Learning is Essential for Students. (Edutopia). Available at https://www.edutopia.org/blog/why-sel-essential-for-students-weissberg-durlakdomitrovich-gullotta. [Accessed 10 September 2021]

Weissberg, R. P., Durlak, J. A., Domitrovich, C. E. \& Gullotta, T. P. (2015). Social and emotional learning: Past, present, and future. In J. A. Durlak, R. P. Weissberg \& T. P. Gullotta (Eds.), Handbook of Social and Emotional Learning: Research and Practice. New York, NY: Guilford, pp 3-19.

Westbrock, H.B., van Rens, L., van den Berg, E. \& Janssen, F. (2020). A practical approach to assessment for learning and differentiated instruction. International Journal of Science Education, 42(6), pp. 955-976. doi:10.1080/09500693.2020.1744044

Wiliam, D. (2009). An integrative summary of the research literature and implications for a new theory of formative assessment. In H. L. Andrade \& G. J. Cizek (Eds.), Handbook of Formative Assessment. New York: Routledge, pp. 18-40.

Wiliam, D. (2011). What is assessment for learning? Studies in Educational Evaluation, 37(1), pp. 3-14. doi:10.1016/j.stueduc.2011.03.001

Wiliam, D. (2018). Embedded Formative Assessment. Bloomington, IN: Solution Tree Press.

Wiliam, D., \& Leahy, S. (2015). Embedding Formative Assessment. Practical Techniques for K-12 Classrooms. Florida, USA: Learning Sciences International.

Wiliam, D. \& Thompson, M. (2007). Integrating assessment with instruction: What will it take to make it work? In C. A. Dwyer (Ed.), The Future of Assessment: Shaping Teaching and Learning. Mahwah, NJ: Lawrence Erlbaum, pp. 53-82. doi:10.4324/9781315086545-3 
Willis, J. (2010). Assessment for learning as a participative pedagogy. Assessment Matters, 2, pp. 65-84. doi:10.18296/am.0079

Willis, J. (2011). Affiliation, autonomy and assessment for learning. Assessment in Education: Principles, Policy and Practice, 18(4), pp. 399-415. doi:10.1080/0969594X.2011.604305

Wylie, E. C., Lyon, C. J. \& Mavronikolas, E. (2008). Effective and Scalable Teacher Professional Development: A Report of the Formative Research and Development Princeton, NJ: Educational Testing Service. doi:10.1002/j.2333-8504.2008.tb02151.x 
